\title{
Capital Investment and Saving *
}

\author{
Reviewed by Francis H. Schott **
}

In his famous book on Capital in the American Economy (Princeton University Press, 1961), Nobel-Prize-winning economist Simon Kuznets tracked the history of U.S. economic growth over a 100-year span and concluded that it had indeed been fueled by large-scale capital formation financed by private-sector saving. Although his book dealt with history rather than with forecasting, Kuznets did briefly consider "The Past as a Prologue" in his last chapter and had the following cogent comment on then-emerging trends :

"... the recently increasing diversion of product to current consumption by governments, combined with high levels of consumer demand, has limited capital formation and savings... Inflationary pressures may well continue, with the result that part of the savings needed for capital formation and government consumption will be extracted through this particular mechanism..." (pp. 459 \& 460).

Fifteen years later, in the mid-1970s, there was ample reason to be concerned about the growth performance of the U.S. economy and the reasons for clearly adverse trends in inflation, capital formation, savings and productivity. Equally striking, however, was the widespread indifference to these trends. Part of the reason for neglect was the emerging energy problem - an obvious obstacle in the way of satisfactory economic performance. More fundamentally, however, U.S. theoretical and policy-oriented thinking was dominated by "demand-side economics" - the notion that appropriate manipulation of aggregate demand would bring forth appropriate supply responses, which therefore did not in themselves require special attention.

The American Council of Life Insurance (ACLI), the leading U.S. trade organization of life insurance companies, decided to help remedy this deficiency by commissioning a broad survey of our knowledge of the savings and investment process in the United States, thus updating Professor Kuznets' work, which the industry had also sponsored.

* A 3-volume Study, edited by George M. von Furstenberg, sponsored by the American Council of Life Insurance, Ballinger Publishing Co., Cambridge (Mass.), 1979-80; U.S. $\$ 90.00$.

** Senior Vice President and Chief Economist, Equitable Life Assurance Society of the United States, New York. 
The ACLI has a 30-year history of assisting economic and financial research by distinguished scholars. This activity, carried forward on a modest budget, is supervised by a small committee of senior officials of member companies and by the industry's chief economist. It should be understood that the industry's "sponsorship" consists only of reaching a broad understanding with one or more scholars about the subjects to be covered and payment of modest honoraria for the papers received. There is no control, and in fact no influence, over the content and conclusions of commissioned papers, which typically must find a commercial publisher to become generally available.

It was decided in this case that a group of professors rather than a single person would be required to cover the voluminous facets of the subject at hand. Direction of the project was entrusted to Prof. George von Furstenberg, then of Indiana University and now with the International Monetary Fund. Over a three-year span, 1976-79, Prof. von Furstenberg engaged 35 contributing authors and assembled their interrelated papers in three volumes, entitled, respectively, Social Security versus Private Saving (Vol. 1) ; The Government and Capital Formation (Vol. 2) ; and Capital, Efficiency and Growth (Vol. 3).

What, then, is the status of capital formation and of the underlying savings and investment processes in the United States? One cannot expect unequivocal conclusions from a diverse group of scholars. Nor should one look for uniform coverage of what one would judge to be the main subjects from a private enterprise or insurance company point of view. Yet, despite divergencies in personal views, subject specifications and methodologies, there are many common and broad impressions one obtains in sampling all and carefully perusing some of these papers.

No doubt the main impression is that concern over the state of private savings and investment in the U.S. is well founded. Turning to the main theme of Volume 1 , for example, Professors Bulent Gultekin and Dennis Logue conclude in Chapter 3 that "the greater the tax earmarked for old-age support, the less people will currently save" (p. 128). They add that "only by reducing social security benefit levels or at least by not raising them... can one be reasonably sure that personal saving will not decline further."

One needs some background to understand the need for asking questions about the relationship between private savings and the level of Social Security taxes and benefits. In the first three decades of Social Security (the 1930s through the 1950s) the following arguments were typically marshaled for the proposition that Social Security did not impinge upon private savings: (1) Social Security constituted a "floor of protection" (i.e. was charecterized by a low level of taxes and benefits) and therefore exacted tribute largely from those who would not otherwise have saved or bought private insurance anyway ; (2) by providing a "floor of protection" Social Security actually encouraged savings via private pension plans - it made the attainment of retirement goals realistic ; and (3) this effect was reinforced by the push toward earlier retirement (partly induced by Social Security) and its attendant need for more workinglife savings. These arguments were not only plausible but were defensible on the basis of reasonable empirical tests until the early 1960's. 
Life insurance executives and a few academics were aware throughout these decades that net improvements in the savings rate from Social Security crucially depended upon the level of its taxes and benefits - i.e., what was positive in moderation could prove deleterious in excess. Thus, it was correctly pointed out that a " pay-asyou-go" (unfunded) Social Security system did not in itself constitute saving and assist capital formation. But these common-sense observations were disregarded as politicians caught on to the advantages of systematically upgrading Social Security. Between 1970 and 1979 the Social Security benefits of an average retiree with no dependents rose from $25 \%$ to $34 \%$ of average gross weekly earnings of those currently employed, while social security taxes (on employers and employees combined) increased from $9.6 \%$ to $12.6 \%$ of wages covered under the Social Security law. (The indexation to the cost of living index of Social Security, legislated in 1972 and fully effective since 1975, has been a material influence in these developments).

Only recently has the accumulating statistical material become adequate to "prove" the damage from this expansion, as Gultekin and Logue do. In the U.S. context, therefore, the von Furstenberg volumes may mark a turning point in the intellectual if not in the political appraisal of Social Security versus Private Saving (the pointed title of Volume 1).

It is hardly necessary to add that these findings will remain controversial. First, the determinants of private savings include many variables other than the desired provision for survivors and for old age - variables such as nominal and real income and their relative movement, the level of personal wealth, and special savings incentives (including tax and regulatory provisions). Second, the experience of other countries does not uniformly bear out the contention that enlarged public security schemes reduce personal saving. In the case of Sweden, Aleksander Markowski and Edward Palmer conclude that personal savings have declined but national savings have increased as a result of the partially funded public pension scheme instituted in 1960 (Chapter 5 of Volume 1). In the case of Great Britain, David Barros notes that "the total of personal saving has not been significantly affected by the provision of state welfare benefits" (Chapter 6 of Volume 1).

The thrust of the conclusions of Volume 2 is that government budgets and regulations do have a major impact on private capital formation, and that in general a rising role of government is adverse to capital formation. Some history may help to clarify the implications of these conclusions. Federal government expenditures accounted on average for $19 \%$ of GNP in the years 1960-64; in the second half of the 1970s that percentage had risen to 22. Since federal revenues did not grow as rapidly as outlays, the deficit rose from an average of $0,3 \%$ of GNP in the early ' 60 s to $2.2 \%$ in the late 1970 s. It is also noteworthy that "transfer payments" nearly doubled in size relative to the economy in that time span - from $4.9 \%$ of GNP to $9.1 \%$. (These are direct payments to persons rather than outlays for goods and services and include Social Security as well as welfare, medical assistance, unemployment pay and many other programs.)

The net effects of these developments on capital formation are debatable. The main argument focuses on the possibility that "demand management", with the aim 
of maintaining or restoring full employment through consumption stimulus, is on balance beneficial even to capital investment. (A market for rising output from enlarged investment is assured). Von Furstenberg himself analyzes this argument and others that seek to distinguish the actual trends in the U.S. from hypothetical cases in which increased government expenditures are fully tax-financed and those in which the government devotes its rising expenditures directly to capital investment (Chapter 6 of Vol. 2). In essence, he concludes that in any and all cases the theoretical presumption remains that a rising long-term share of government in GNP reduces total capital formation. Again, this conclusion will remain controversial - there are high-investment, high-growth countries in which the total tax take of the government has over long periods exceeded the corresponding share in the U.S. - e.g., the German Federal Republic and Canada. (The total tax take / GNP share presumably corresponds roughly to government outlay / GNP figures. The tax-take figures are more readily available for international comparisons).

Von Furstenberg would be the first to acknowledge not only such exceptions but also that there are vital subsidiary issues that can affect the degree to which his general view holds. One such issue is the basic tax structure - is it conducive or harmful to savings and investment ? David Bradford examines the case for a broadbased federal consumption tax (such as the European value-added taxes) as a partial substitute for the high U.S. federal income tax. This tax is increasingly recognized as onerous to saving and investment, partly because inflation forces tax payers into progressively higher brackets as their current-dollar income rises even if their real income remains unchanged (Chapter 1 of Vol. 2). Although Bradford favors the reform mentioned for equity reasons he refrains from claiming for certain that substantial gains in savings and investment would result.

Another vital subsidiary issue is whether capital formation might be stimulated by favorable tax treatment within the context of rising government expenditures and substancial deficits. Several studies in Volume 2 evaluate proposals for strengthening the existing investment tax credit, for adjusting upward the depreciation allowances on business investment, for reducing the general level of the corporate profits tax, and for reducing the "double taxation" of profits at the corporate and individual levels. The potential gain for investment and economic growth from such measures is judged to be significant, but there is disagreement among the scholars about the relative effectiveness of the various proposals. In addition, the discussion is hampered by the partial nature of the analysis. It is difficult to come up with worthwhile suggestions in the absence of clear alternatives either for cutting government expenditures or for raising other taxes in correspondence with the investment tax relief sought.

The President's Council of Economic Advisers, in discussing the productivity of the U.S. economy, has noted that :

“... the underlying trend in productivity growth since 1973 has been substantially lower than in earlier periods. Between 1948 and 1965, productivity growth in the private non-farm sector averaged $2.6 \%$ per year. In 1965-73, this rate declined to $2.0 \%$. Since 1973 , private non-farm productivity growth has averaged less than one percent per year." (Economic Report of the President, transmitted to Congress January 1979, p. 67). 
In the Economic Report of January 1980 (p. 35), the Council added that the relevant figure for 1979 had turned out to be a minus $2.2 \%$.

The causes and possible cures of the productivity problem constitute the core of Volume 3 of the von Furstenberg study. The results are not very satisfactory in that there are five to ten good candidates for the "main" explanation, none of which can be clearly singled out as the culprit. The Council of Economic Advisers in its 1979 Report (pp. 68-69) names three causes in rough order of decreasing relative importance - first, a lower rate of private capital formation and a consequent lowering of the growth rate of capital per worker ; second, a "dramatic shift" in the age-sex composition of the labor force with sharp relative gains for the young and for females who may have less experience and skills than older males during the beginning years of the change; and, third, increased economic and social regulation.

The most searching paper of Volume 3 is "The Role of Capital in U.S. Economic Growth, 1948-76" by Barbara M. Fraumeni and Dale W. Jorgenson (Chapter 2). The authors reaffirm that "the contribution of capital input is the most important source of growth in aggregate value" (p. 172), but they have hit upon the important idea of decomposing capital into "quantity" and "quality". The latter is roughly equated with technology or, more precisely, the rate of technological change. Gains from this source have sharply slowed since the mid-1960's. This in turn leads to the intriguing conclusion that remedial measures might not aim broadside at investment stimulus but more precisely at spurring technological innovation.

One may wonder where such an attempt might lead. There are as many people arguing that "basic" research is being neglected as there are people arguing that entrepreneurial exploitation of innovation (and not inventions themselves) has been stifled. The opposing sides would then go on to argue their respective cases for more assistance to basic research by government and industry on the one hand, and for liberalization of capital gains taxation on the other hand.

Nevertheless, other studies in this volume bolster the case for a partially "qualitative" approach to the strengthening of the capital base. Thus, M. Ishaq Nadiri shows in "Contributions and Determinants of Research and Development Expenditures in U.S. Manufacturing Industries" (Chapter 5) that the rate of growth of " $R$ \& $D$ " (Research and Development) expenditures has slowed since the mid-1960's and that such expenditures are positively correlated with increases in the economy's productive capacity. Not surprisingly, there are now numerous proposals for stimulating " $R$ \& $D$ " as distinct from capital investment per se.

One of the most intriguing examinations of special problems on the productivity side is that of "Government-Induced Biases in the Allocation of the Stock of Fixed Capital in the United States" by Patrick H. Hendershott and Sheng-Cheng $\mathrm{Hu}$ (Chapter 4). The U.S. has long prided itself on its methods and results in providing housing for the population. It is well known that direct public housing activity is relatively less important than in many European countries. The single most important subsidy is the deductibility from gross income, for tax computation purposes, of mortgage interest. This subsidy roughly rises with inflation as the inflation "infiltrates" mortgage interest rates, and the authors contrast this adaptability with the lag in 
business depreciation allowances tied to the original cost of plant and equipment. They conclude that the result is a measurable and significant distortion of investment incentives and actual capital allocation in favor of households and against business.

This conclusion is not really surprising to anyone familiar with "shortage economies" such as those of Eastern Europe. In these countries, residential housing typically competes with, and is often crowded out by, industrial investment through official planning and allocation. In the U.S., however, such a juxtaposition is quite novel. "Demand-side economics" would deny any dilemma in capital allocation, except perhaps for brief periods at the very peak of cyclical expansions.

In summary :

(1) Von Furstenberg and his associates have made a major contribution in the search for answers to vital questions surrounding the long-term potential and the vitality of the U.S. economy. Virtually every relevant facet of savings and investment and their interrelationship with government action is explored in a professionally competent manner. The three-volume study therefore is a recommended reference for scholars and academically inclined businessmen who are interested in the core subjects determining the performance of free-market-oriented economies.

(2) There is a noticeable revival of public interest in the main concerns of this study in the United States. The change in atmosphere has been clearly apparent even during the three-year period of preparation of the study, and this change will be enhanced by the preponderance of the conclusions drawn. Thus, tax change proposals designed to improve savings and investment are discussed with increasing seriousness and improving chances for enactment. Yet, one has to admit that no real dent has as yet been made into the "philosophy of entitlement" of the beneficiaries of federal government expenditures. One has to be optimistic rather than realistic to believe that the government's role in the U.S. economy will be significantly diminished by the mid-1980's.

(3) This or any other scholarly study requires careful perusal to be fully useful to the practicing businessman interested in broad economic and policy issues. The evidence presented is frequently ambiguous and hence inconclusive. This very fact, however, enhances the credibility of the conclusions one may legitimately draw. No one can put aside this distinguished work without affirming, or reaffirming, the importance of savings and investment in economic progress. 